\title{
EVALUASI FAKTOR RISIKO YANG MEMPENGARUHI LUARAN OPERASI ENDORECTAL PULL-THROUGH SOAVE MODIFIKASI SOEWARNO PADA PENYAKIT HIRSCHSPRUNG
}

\section{Yuliaji Narendra Putra}

Program Studi Ilmu Bedah, Fakultas Kedokteran Universitas Gadjah Mada, RSUP Dr. Sardjito. Korespondensi: yp_narendra@yahoo.com.

\begin{abstract}
ABSTRAK
Tujuan: untuk mengevaluasi luaran operasi endorectal pull-through Soave modifikasi Soewarna pada pasien Hirschsprung. Metode: penelitian ini adalah penelitian deskriptif pada 48 penderita Hirschsprung, dimana data dikumpulkan dengan wawancara langsung ke orang tua penderita. Setelah didapatkan skoring, kemudian dinilai angka keberhasilan penatalaksanaan operasi Soave modifikasi Soewarno, kemudian dilakukan analisis dengan menggunakan uji statistik Chi-kuadrat. Analisis antara skor Klotz dengan faktor prognostik, seperti berat badan lahir, status gizi, berat badan saat operasi, kadar albumin, kadar hemoglobin, kadar kalium, lama perawatan, dan jenis kelamin di analisis dengan uji Chi-Kuadrat. Hasil: pada penelitian ini, didapatkan pada faktor-faktor risiko yang mempengaruhi luaran operasi endorectal pull-through Soave modifikasi Soewarno adalah status gizi $\mathrm{p}<0,001$ dengan $R R 28,0$ dan albumin $p=0,047$ dengan $R R$ 1,23. Faktor risiko hemoglobin ( $p=0,372$ ), kalium $(\mathrm{p}=0,256)$, berat badan lahir $(\mathrm{p}=0,66)$, berat badan saat operasi $(\mathrm{p}=0,0605)$, lama operasi $(p=0,941)$, dan lama perawatan $(p=0,683)$ tidak berpengaruh secara signifikan. Simpulan: Status gizi dan kadar albumin menjadi faktor prognosis signifikan terhadap luaran pasien dengan penyakit Hirchsprung yang dilakukan tindakan operasi Soave modifikasi Soewarno.
\end{abstract}

Kata kunci: penyakit Hirschsprung, faktor prognostik, skor Klotz.

\section{EVALUATION OF RISK FACTORS AFFECTING OUTCOME OF SOAVE ENDORECTAL PULL-THROUGH OPERATION SOEWARNO MODIFICATION IN HIRSCHSPRUNG'S DISEASE}

\section{Yuliaji Narendra Putra}

General Surgery Training Programme, Faculty of Medicine Gadjah Mada University, Dr. Sardjito Hospital. Correspondence: yp_narendra@yahoo.com.

\begin{abstract}
Objective: to evaluate the outcome of Soave endorectal pull-through operation with Soewarno modification in Hirschsprung patients. Methods: this study was a descriptive study of 48 Hirschsprung patients, where data were collected by direct interviews to the patient's parents. After scoring then assessed the success rate of Soave operation Soewarno modification, then analyzed by using statistic Chi-square test. The analysis between Klotz score with prognostic factors, such as birth weight, age of Soave, nutritional status, body weight during surgery, albumin level, hemoglobin level, potassium level, length of treatment, and sex in analysis with Chi-Square test. Results: the significant prognostic factors affected the outcome of Soave endorectal pull-through operation with Soewarno modification in Hirschsprung patients were nutritional status ( $R R 28 ; p=0.047)$ and hemoglobin (RR 1.14; $\mathrm{p}<0.001)$. Others factors like hemoglobin $(\mathrm{p}=0.372)$, kalium $(\mathrm{p}=0.256)$, birth weight $(\mathrm{p}=0.66)$, weight before surgery $(\mathrm{p}=0.0605)$, duration of surgery $(\mathrm{p}=0.941)$, dan length of hospital stay $(\mathrm{p}=0.683)$. Conclusion: nutritional status and hemoglobin level were the most significant factors that
\end{abstract}


affected the outcome of Hirchsprung's disease performed Soave operation with Soewarno modification.

Keywords: Hirschsprung's disease, prognostic factor, Klotz score.

\section{PENDAHULUAN}

Penyakit Hirschsprung disebut juga megakolon kongenital merupakan kelainan tersering dijumpai sebagai penyebab obstruksi usus pada neonatus. Pada penyakit ini, tidak dijumpai pleksus mienterikus sehingga bagian usus tersebut tidak dapat mengembang. ${ }^{1,2}$ Angka insidensi Hirschprung adalah 1 diantara 5000 kelahiran, maka dengan penduduk 220 juta dan tingkat kelahiran 35 per mil, diperkirakan akan lahir 1400 bayi setiap tahunnya dengan penyakit Hirschsprung di Indonesia. $^{3-6}$

Pasien dengan penyakit Hirschsprung harus dikelola segera setelah diagnosis ditegakkan. ${ }^{3}$ Prosedur Soave disebut juga prosedur pull-through ekstramukosa endorektal dari Soave. Di Subbagian Bedah Anak FK UGM/RSUP Dr.Sardjito Yogjakarta, Soave dikerjakan mulai awal tahun 1990, dalam pelaksanaannya didapatkan kesulitan dalam pengupasan mukosa, sehingga diciptakan teknik prosedur modifikasi Soewarno dan hingga saat ini dijadikan prosedur tetap untuk penanganan penderita Hirschsprung di Sub Bagian Bedah Anak UGM/RS Dr. Sardjito Yogyakarta. Walaupun begitu, proses penyembuhan atau keberhasilan setelah operasi sangat tergantung pada sistem imun dan kemampuan adaptasi pasien. Dalam hal ini yang berpengaruh adalah usia, kadar hemoglobin, kadar kalium serum, kadar albumin serum, status gizi, berat badan lahir, berat badan saat operasi, dan lama perawatan. Tujuan penelitian ini mengevaluasi luaran operasi endorectal pull-through Soave modifikasi Soewarno pada pasien Hirschsprung.

\section{METODE}

Penelitian ini dilakukan dengan rancangan analitik deskriptif cross sectional pada penderita Hirshsprung yang ditatalaksana dengan metode Soave modifikasi Soewarno di RS. Dr. Sardjito Yogyakarta antara bulan Januari 2005 sampai Februari 2008. Tujuan penelitian adalah untuk mencari faktor risiko yang berpengaruh terhadap luaran pasien Hirschsprung yang ditatalaksana dengan prosedur Soave modifikasi Soewarno.

Parameter yang dinilai untuk variabel independen (risiko) meliputi usia, kadar hemoglobin, kadar kalium serum, kadar albumin serum, status gizi, berat badan lahir, berat badan saat operasi, dan lama perawatan. Variabel dependen atau luaran hasil operasi dinilai dengan skor Klotz. Semua parameter didapatkan datanya dari rekam medis dan wawancara atau pengukuran langsung. Skor Klotz $\leq 13$ dinyatakan baik/cukup dan dinyatakan jelek/kurang jika skor Klotz $>13$.

Pada seluruh subjek penelitian, harus menyetujui informed consent dari orang tuanya. Data usia, status gizi, dan berat badan diperoleh dengan melakukan alloanamnesis dan pemeriksaan fisik. Pemeriksaan barium enema dilakukan untuk mengetahui penyakit Hirschsprung, seperti adanya penyempitan rektosigmoid, daerah transisi, daerah dilatasi dan ketidakteraturan mukosa. Tindakan bedah definitif dilakukan pada semua pasien 
yang menderita penyakit Hirschsprung yang sudah dikerjakan kolostomi. Jenis prosedur bedah yang dikerjakan adalah prosedur pull-through ekstramukosa endorektal prosedur Soave modifikasi Soewarno.

Prosedur operasi modifikasi Soewarno dilakukan dengan irisan transversal pada dinding depan abdomen mulai $4 \mathrm{~cm}$ sebelah medial SIAS (spina iliaka anterior superior) kanan melalui garis langer sampai mencapai lobang kolostomi. Irisan delanjutkan melengkung ke kraniolateral secukupnya. Arteri hemorrhoidalis superior dan arteri sigmoidalis di identifikasi selanjutnya diikat dan dipotong. Dilakukan reseksi kolon 3-4 cm di proksimal kolostomi dan 1-2 cm di proksimal refleksi peritoneum. Pungtum proksimal kemudian ditutup, dilakukan pengupasan mukosa rektum dari lapisan seromuskuler, dengan cara memegang mukosa dengan 4 buah klem Allis. Irisan pertama dilakukan secara tajam selanjutnya seromuskuler dipegang dengan 4 buah klem Allis, selanjutnya dilakukan pengupasan secara tumpul. Pengupasan ke anal sejauh mungkin sehingga mencapai linea dentata. Selanjutnya dilakukan pembebasan kolon proksimal yang sehat, sampai cukup untuk diteroboskan keluar anus. Pembebasan ini harus hati- hati sehingga jalinan pembuluh darah tetap terjamin. Bila sudah dinilai cukup, maka operasi dilanjutkan lewat peritoneum. Anus disiapkan, kemudian cerobong mukosa ditarik dengan jalan memasukkan sonde khusus dengan ujung berbentuk kepala yang lebih besar. Mukosa diikat pada leher sonde tersebut dan ditarik keluar secara melipat terbalik. Kolon yang sehat kemudian diteroboskan di dalam cerobong mukosa. Lapisan mukosa difiksasi dengan kolon dengan benang plain catgut, dan dipasang rectal tube di dalam kolon yang diteroboskan tersebut sampai melewati sfingter ani. Operasi dilanjutkan lewat abdominal, vesika urinaria, dan organ abdomen lain ditata kembali, cerobong seromuskuler difiksasi dengan serosa kolon yang diteroboskan dengan chromic catgut. Dilakukan appendektomi insidental, rongga abdomen dicuci dan ditutup lapis demi lapis. Sepuluh hari setelah dioperasi endorectal pull-through, telah terjadi perlekatan antara cerobong seromuskuler dengan serosa kolon. Dilakukan pemotongan pungtum kolon yang diteroboskan $1 \mathrm{~cm}$ proksimal linea dentata, dilanjutkan dengan penjahitan mukosa dengan mukosa. Selama 3 hari rectal tube terus dipasang pada rektum yang baru sehingga gangguan obstruksi akibat edema di daerah anorektal dapat dihindari. ${ }^{8}$

Setelah operasi, peneliti mewawancara orang tua pasien dengan menggunakan kuesioner berisi tabel skor Klotz (Tabel 1) terhadap hasil pembedahan operasi definitif metode Soave modifikasi Soewarno kemudian dibuat skoring Klotz tiap pasien berdasarkan kuisioner hasil wawancara peneliti dengan orang tua pasien. Hasil skoring Klotz dicari korelasinya dengan faktor prognostik disajikan secara tekstular dan tabular dan diuji statistik dengan Chi-kuadrat.

\section{HASIL}

Karakteristik subjek penelitian dari 48 kasus didapatkan jenis kelamin laki-laki terdapat 35 orang $(72,92 \%)$ dan perempuan ada 13 orang $(27,08 \%)$. Ratarata usia $627,32 \pm 525,36$ hari dengan usia terendah 1 hari dan maksimum 1980 hari (5,42 tahun). Berat badan lahir rata-rata $2,93 \pm 0,27 \mathrm{~kg}$ dengan berat minimal 1,90 $\mathrm{kg}$ dan berat maksimal 3,60 kg. Status gizi 
yang baik ada 41 orang $(85,4 \%)$, sedangkan status gizi jelek ada 7 orang $(14,6 \%)$.

Tabel 1. Tabel Skor Klotz

\begin{tabular}{|c|c|c|c|}
\hline No & Variabel & Kondisi & Skor \\
\hline \multirow[t]{6}{*}{1} & Defekasi & 1-2 kali sehari & 1 \\
\hline & & 2 hari sekali & 1 \\
\hline & & $3-5$ kali sehari & 2 \\
\hline & & 3 hari sekali & 2 \\
\hline & & $>4$ hari sekali & 3 \\
\hline & & $>5$ hari sekali & 3 \\
\hline \multirow[t]{3}{*}{2} & Kembung & Tidak Pernah & 1 \\
\hline & & Kadang - kadang & 2 \\
\hline & & Terus Menerus & 3 \\
\hline \multirow[t]{3}{*}{3} & Konsistensi & Normal & 1 \\
\hline & & Lembek & 2 \\
\hline & & Encer & 3 \\
\hline \multirow[t]{2}{*}{4} & Perasaan ingin $\mathrm{BAB}$ & Terasa & 1 \\
\hline & & Tidak terasa & 3 \\
\hline \multirow[t]{3}{*}{5} & Soiling / Kecepirit & Tidak pernah & 1 \\
\hline & & Bersama Flatus & 2 \\
\hline & & Terus menerus & 3 \\
\hline \multirow[t]{3}{*}{6} & Kemampuan menahan & Lebih dari satu menit & 1 \\
\hline & feses yang akan keluar & $\begin{array}{l}\text { Kurang dari satu } \\
\text { menit }\end{array}$ & 2 \\
\hline & & Tidak bisa & 3 \\
\hline \multirow[t]{3}{*}{7} & Komplikasi Lain & Tidak ada & 1 \\
\hline & & Minor & 2 \\
\hline & & Mayor & 3 \\
\hline
\end{tabular}

Penilaian hasil skoring:
a. Skor 7: sangat baik
b. skor 8-9: baik
c. Skor 10-13: cukup
d. Skor 14-lebih: kurang/ jelek

Hasil analisis Klotz terhadap jenis kelamin, hemoglobin, dan kalium, secara statistik tidak bermakna dimana p>0,05. Skor Klotz bermakna secra statistik pada status gizi dan albumin, yang mana status gizi dan albumin yang baik memiliki skor Klotz yang baik (Tabel 2). Pada Tabel 3, hasil analisis Klotz terhadap rata-rata umur, berat badan lahir, berat badan saat operasi, lama operasi, dan lama perawatan secara statistik tidak bermakna $\mathrm{p}>0,05$.

\section{DISKUSI}

Pasien dengan penyakit Hirschsprung harus dikelola segera setelah diagnosis ditegakkan. Pengobatan definitif aganglionosis kolon adalah pembedahan dengan membuang semua bagian yang aganglionik, kemudian membawa usus (kolon) yang normal persarafannya (ganglionik) ke anus dengan memperhatikan kontinensi. Tanpa penanganan, tingkat mortalitas penyakit ini $80 \%$, di mana pasien penyakit Hirschsprung akan meninggal pada bulanbulan pertama kehidupannya, sebagian besar pada masa neonatus. Keterlambatan dan kegagalan tindakan bedah, baik tindakan bedah sementara maupun bedah definitif dapat mengakibatkan cacat bahkan kematian. $^{3}$

Prosedur Soave merupakan prosedur pembedahan yang paling sering dilakukan. Prosedur Soave konvensional dilakukan dengan pemisahan mukosa dan seromuskuler dengan prokain hidroklorida, tepat di proksimal masuknya arteri hemorrhoidalis superior ke lapisan otot rektum. Pengupasan lapisan seromuskuler dari lapisan mukosa dengan kasa bulat dan kecil. Setelah lapisan seromuskuler terpisah dengan mukosa dilakukan pemotongan mukosa secara melintang dilanjutkan dengan pembebasan kolon proksimal sepanjang $30-50 \mathrm{~cm}$ di proksimal daerah transisi. Di perineum, mukosa kolon ditarik keluar lubang anus dan dijahit. $^{7}$

Untuk lebih memudahkan dengan hasil luaran yang lebih baik, dilakukan prosedur operasi modifikasi Soewarno yang dilakukan dengan irisan transversal pada dinding depan abdomen mulai $4 \mathrm{~cm}$ sebelah medial SIAS kanan melalui garis langer sampai mencapai lobang kolostomi. Irisan dilanjutkan melengkung ke kraniolateral secukupnya. Arteri hemorrhoidalis superior dan arteri 
sigmoidalis di identifikasi selanjutnya

diikat dan dipotong.

Tabel 2. Analisis uji Chi-kuadrat antar faktor risiko dengan skor Klotz

\begin{tabular}{|c|c|c|c|c|c|}
\hline \multirow[t]{2}{*}{ Variabel } & \multicolumn{2}{|c|}{ Skor Klotz } & \multirow[t]{2}{*}{ RR } & \multirow[t]{2}{*}{$95 \% \mathrm{CI}$} & \multirow[t]{2}{*}{$\mathrm{p}$} \\
\hline & Jelek & Baik & & & \\
\hline \multicolumn{6}{|l|}{ Jenis kelamin (\%) } \\
\hline Laki-laki & $1(20,0)$ & $12(27,9)$ & \multirow{2}{*}{0,67} & \multirow{2}{*}{$0,08-5,48$} & \multirow{2}{*}{0,706} \\
\hline Perempuan & $4(80,9)$ & $31(72,1)$ & & & \\
\hline \multicolumn{6}{|l|}{ Status gizi (\%) } \\
\hline $\begin{array}{l}\text { Kurang baik } \\
\text { Baik }\end{array}$ & $\begin{array}{l}4(80) \\
1(20)\end{array}$ & $\begin{array}{l}2(4,7) \\
41(95,3)\end{array}$ & 28,0 & $3,72-210,5$ & 0,000 \\
\hline \multicolumn{6}{|l|}{ Albumin (\%) } \\
\hline $\begin{array}{l}\text { Jelek }(<3,5 \mathrm{~g} / \mathrm{dL}) \\
\text { Baik }\end{array}$ & $\begin{array}{l}0(0) \\
5(100)\end{array}$ & $\begin{array}{l}21(48,8) \\
22(51,2)\end{array}$ & \multirow[t]{2}{*}{1,23} & $1,02-1,47$ & 0,047 \\
\hline \multicolumn{5}{|l|}{ Hemoglobin (\%) } & \\
\hline $\begin{array}{l}\text { Jelek }(<11 \mathrm{~g} / \mathrm{dL}) \\
\text { Baik }\end{array}$ & $\begin{array}{l}0(0) \\
5(100)\end{array}$ & $\begin{array}{l}6(14) \\
37(86)\end{array}$ & 1,14 & $1,02-1,27$ & 0,372 \\
\hline \multicolumn{6}{|l|}{ Kalium (\%) } \\
\hline $\begin{array}{l}\text { Jelek }(<3,5 \mathrm{mmol} / \mathrm{L}) \\
\text { Baik }\end{array}$ & $\begin{array}{l}0(0) \\
5(100)\end{array}$ & $\begin{array}{l}9(20,9) \\
34(79,1)\end{array}$ & 1,15 & $1,02-1,29$ & 0,256 \\
\hline
\end{tabular}

$\mathrm{RR}$ : risiko relatif, $\mathrm{CI}$ : confidence interval

Tabel 3. Hasil skor Klotz terhadap rata-rata umur, berat badan lahir, berat badan saat operasi, dan lama operasi, dan lama perawatan

\begin{tabular}{lccc}
\hline Variabel & \multicolumn{2}{c}{ Skor Klotz (rata-rata \pm standar deviasi) } & $\mathrm{p}$ \\
\cline { 2 - 3 } & Jelek & Baik & \\
\hline Umur (hari) & $439,60 \pm 406,11$ & $649,1 \pm 537,1$ & 0,405 \\
Berat badan lahir (kg) & $2,98 \pm 0,265$ & $2,93 \pm 281,47$ & 0,660 \\
Berat badan saat operasi (kg) & $11,40 \pm 1,67$ & $8,1 \pm 3,84$ & 0,065 \\
Lama operasi (jam) & $2,45 \pm 0,447$ & $2,47 \pm 0,60$ & 0,941 \\
Lama perawatan (hari) & $12,6 \pm 1,34$ & $13,39 \pm 4,26$ & 0,683 \\
\hline
\end{tabular}

Dilakukan reseksi kolon 3-4 $\mathrm{cm}$ di proksimal kolostomi dan 1-2 cm di proksimal refleksi peritoneum. Pungtum proksimal kemudian ditutup, dilakukan pengupasan mukosa rektum dari lapisan seromuskuler, dengan cara memegang mukosa dengan 4 buah klem Allis. Irisan pertama dilakukan secara tajam selanjutnya seromuskuler dipegang dengan 4 buah klem Allis, selanjutnya dilakukan pengupasan secara tumpul. Pengupasan ke anal sejauh mungkin sehingga mencapai linea dentata. Selanjutnya dilakukan pembebasan kolon proksimal yang sehat, sampai cukup untuk diteroboskan keluar anus. Pembebasan ini harus hati- hati sehingga arkade pembuluh darah tetap terjamin. Bila sudah dinilai cukup, maka operasi dilanjutkan lewat peritoneum. Anus disiapkan, kemudian cerobong mukosa ditarik dengan jalan memasukkan sonde khusus dengan ujung berbentuk kepala yang lebih besar. Mukosa diikat pada leher sonde tersebut dan ditarik keluar secara melipat terbalik. Kolon yang sehat kemudian diteroboskan di dalam cerobong mukosa. Lapisan mukosa difiksasi dengan kolon dengan benang plain catgut, dan dipasang rectal tube di dalam kolon yang diteroboskan tersebut sampai melewati sfingter ani. Operasi dilanjutkan lewat abdominal, vesika urinaria, dan organ abdomen lain ditata kembali, cerobong seromuskuler difiksasi 
dengan serosa kolon yang diteroboskan dengan chromic catgut. Dilakukan appendektomi insidental, rongga abdomen dicuci dan ditutp lapis demi lapis. Sepululuh hari setelah dioperasi endorectal pull-through, telah terjadi perlekatan antara cerobong seromuskuler dengan serosa kolon. Dilakukan pemotongan pungtum kolon yang diteroboskan $1 \mathrm{~cm}$ proksimal linea dentata, dilanjutkan dengan penjahitan mukosa dengan mukosa. Selama 3 hari rektal tube terus dipasang pada rektum yang baru sehingga gangguan obstruksi akibat udema di daerah anorektal dapat dihindari. ${ }^{8}$

Di Subbagian Bedah Anak FK UGM/RSUP Dr.Sardjito Yogjakarta, Soave dikerjakan mulai awal tahun 1990, dalam melaksanakan tersebut didapatkan kesulitan dalam pengupasan mukosa, sehingga diciptakan teknik prosedur modifikasi Soewarno dan hingga saat ini dijadikan prosedur tetap untuk penanganan penderita Hirschsprung di Sub Bagian Bedah Anak UGM/RS Dr. Sardjito Yogyakarta. Walaupun begitu, proses penyembuhan atau keberhasilan setelah operasi sangat tergantung pada sistem imun dan kemampuan adaptasi pasien. Dalam hal ini yang berpengaruh adalah Usia,kadar hemoglobin, kadar kalium serum, kadar albumin serum, status gizi, berat badan lahir, berat badan saat operasi, dan lama perawatan.

Hasil analisis skor Klotz pada pasien dengan penyakit Hirchsprung yang dilakukan tindakan operasi Soave modifikasi Soewarno dipengaruhi faktor prognosis berupa status gizi $(\mathrm{p}=0,000$ dengan $R R$ 28,0) dan albumin $(p=0,047$ dengan RR 1,23) yang secara statistik signifikan. Sedangkan faktor lain seperti jenis kelamin, hemoglobin, kalium, umur, berat badan lahir, berat badan saat operasi, lama operasi, dan lama perawatan tidak berpengaruh pada skor Klotz.

\section{SIMPULAN}

Teknik operasi endorectal pull-through Soave modifikasi Soewarno merupakan pilihan terapi pada penyakit Hirschsprung. Penyakit Hirchsprung yang dilakukan tindakan operasi Soave modifikasi Soewarno dipengaruhi faktor prognosis berupa status gizi dan albumin, yang dapat mempengaruhi penyembuhan paska tindakan.

\section{DAFTAR PUSTAKA}

1. Soewarno. Tatalaksana penderita penyakit Megakolon kongenital pada bayi dan anak dengan prosedur Duhamel di RSUP Dr. Sardjito. Naskah Pertemuan Ilmiah alumnus FK UGM, HUT FK UGM XI dan HUT RSUP Dr. Sardjito IV. Yogyakarta: FK UGM; 1986.

2. Swenson O, Sherman JO. Diagnosis of Congenital Megacolon: an analysis of 501 patient. $J$ Pediatric Surgery. 1973;8:587-94.

3. Kartono D. Penyakit Hirschsprung, Perbandingan prosedur Swenson dan Duhamel modifikasi [disertasi]. Jakarta: Universitas Indonesia; 1993.

4. Yoshida Jr C. Hirschsprung Disease. Department of Diagnosis Imaging federal of University of Sao Paulo (UNIFEST); 2004.

5. Kartono D. Penyakit Hirschsprung. Jakarta: Sagung Seto; 2004.

6. Holschneider A, Ure BM. Hirschsprung's disease. Dalam: Ashcraft KW, Murphy JP, Sharp RJ, dkk, penyunting. Pediatric Surgery. Edisi ke-3. Philadelphia: Saunders; 2000. p.453-72.

7. Sieber WK. Hirschsprung's Disease. 
Dalam: Welch KJ, Randolph JG, Ravitch MM, dkk, penyunting. Pediatric Surgery. Edisi ke-4. Chicago: Year Book Medical Publisher Inc; 1986. p.995-1019.

8. Santos MC, Giacomantonio JM, Lau HYC. Primary Swenson pull-through compared with multiple-stage pullthrough in the neonate. Journal of Pediatric Surgery. 1999;34:1079-81. 